\title{
Transparency to curb corruption? Concepts, measures and empirical merit
}

\author{
Monika Bauhr ${ }^{1}$ - Marcia Grimes ${ }^{1}$
}

Published online: 15 July 2017

(C) The Author(s) 2017. This article is an open access publication

\begin{abstract}
Policymakers and researchers often cite the importance of government transparency for strengthening accountability, reducing corruption, and enhancing good governance. Yet despite the prevalence of such claims, definitional precision is lacking. As a consequence, approaches to measurement have often cast a wide net, in many cases tapping into the capacity of government institutions more generally, resulting in empirical findings that are ambiguous in terms of interpretation. This paper argues that the operationalization and measure of government transparency should be tailored to two main parameters of the phenomenon under investigation: the principals and purpose of the information. We advance a new measure of government transparency argued to be more suitable for the study of the role of government transparency with respect to probity. The data derive from a survey of public administration experts in 102 countries carried out by the Quality of Government Institute and allow for a more reliable analysis of the effects of transparency on reducing corruption, and the analyses suggest that an association indeed exists.
\end{abstract}

\section{Introduction}

Recent years have seen a strong and sustained call for greater government transparency; international organizations and NGOs advocate transparency as a necessary condition for better government quality, greater accountability, thus limiting the scope for corruption with impunity (see i.e. [1-6]). The theoretical arguments behind the instrumental value of transparency are by now well established and are found in such varying fields as negotiation theory [7], public management [8, 9], and regime effectiveness

Marcia Grimes

Marcia.Grimes@pol.gu.se

Monika Bauhr

Monika.Bauhr@pol.gu.se

1 The Quality of Government (QoG) Institute. Department of Political Science, University of Gothenburg, Gothenburg, Sweden 
[10]. While empirical investigations exist, we argue that the findings leave important questions unresolved due to the breadth of the measures used. Existing definitions provide a useful baseline but greater precision, disaggregation and delineation are needed to allow for more stringent empirical investigation [8, 11]. Transparency is at times conflated with "good governance", and measures tend to tap into closely related phenomena such as accountability, participation and the capacity of government institutions more generally, making it difficult to discern whether observed associations speak to the importance of transparency specifically.

The value of transparency lies in its purported influence on government probity and effectiveness as well as on the functioning of markets. In terms of government performance, and more specifically the prevalence of corruption, the logic is undeniably compelling: since information asymmetries are a primary obstacle to principals' ability to hold agents accountable, lowering the information barrier ought to enable scrutiny and monitoring, without which it is impossible to detect and sanction abuses of public power. Such claims have until recently mostly been the subject of empirical scrutiny in single country and experimental studies, as cross country data on transparency have been wanting (e.g. [12-14]). The research community has fortunately begun to address this gap [15-17, 70]. While a welcome development, we argue that the breadth of the cross-country measures used in these studies risks introducing unhelpful tautologies in empirical investigations of the effects of transparency on other aspects of government.

This paper advances an argument for more delimited operationalizations of transparency that are sensitive to two situational characteristics: the intended principals as well as the expected use of the information, i.e. the purpose. The paper introduces a new measure of government transparency designed to capture these parameters with respect to transparency intended to allow for the detection and exposure of government corruption. A primary aim of the paper is therefore to advocate for greater conceptual and operational precision in studies of transparency in order to disaggregate it from the overall level of political development and capacity of the state. Without such precision, it is impossible to produce reliable analyses of the effects of transparency on the prevalence of corruption.

The paper is structured as follows. Section one discusses the conceptualizations of transparency and existing claims regarding its beneficial implications, and argues that existing definitions, while useful for some research questions, are too broad and allencompassing to allow for explorations of the specific link between transparency and government corruption. Section two discusses the strengths and weaknesses of existing approaches to the measurement of government transparency. We then introduce a novel measure of transparency from the Quality of Government survey of public administration experts, and examine the measure in terms of convergent and divergent validity compared to existing measures of transparency. The analyses then show that the measure introduced here correlates with existing measures of corruption, and that -in contrast to existing measures- the correlation is independent of measures of state capacity and political development more generally.

\section{What is government transparency?}

The arguments linking openness and information to accountability, to democracy and to government honesty and effectiveness are highly compelling theoretically, yet rest on 
many assumptions about how institutions and actors act and interact, assumptions which have only recently become subject to empirical scrutiny [18]. Work to conceptualize transparency has lamentably not developed in step with these trends, which means that conceptualizations and operationalization of transparency have tended to remain at higher levels in the ladder of abstraction ( [19-21], 1040). The measures that have recently emerged, discussed in greater detail below, may hence be useful in exploring the causes and consequences of political development and government openness in the broadest sense, but are less useful - and may potentially even yield misleading results - when used to examine more fine-grained theoretical claims. In order to unpack this argument, we first introduce a more nuanced framework for conceptualizing transparency and then present arguments for why existing definitions, and subsequently attempts at measurement, are useful for addressing some empirical questions but not others.

Transparency is, without a doubt, a multifaceted concept but at times has been made unhelpfully broad to the point that it has been conflated with participation, accountability, state capacity or even corruption, impartiality, and rule of law. Christopher Hood traces the history of the concept and identifies the "broadest doctrine of openness" as "...the doctrine that the general conduct of executive government should be predictable and operate according to published (and as far as possible non-discretionary) rules rather than arbitrarily" ( [22], 14). Hood's analysis illustrates transparency has tended to bleed conceptually into other normative standards of good government. The World Trade Organization states, in an illustrative case in point, that ensuring "transparency" in international commercial treaties typically involves three core requirements: (i) to make information on relevant laws, regulations and other policies publicly available, (ii) to notify interested parties of relevant laws and regulations and changes to them; and (iii) to ensure that laws and regulations are administered in a uniform, impartial and reasonable manner [23]. This definition includes not only making information available and accessible to stakeholders, but also that laws and regulations be administered and implemented in an impartial and predictable manner, a core element of rule of law yet outside the scope of the concept of government transparency. ${ }^{1}$

Many authors take variations of Florini's definition - "the release of information which is relevant for evaluating institutions" [8] - as a point of departure for conceptualizing transparency. Subsequent work has to some extent narrowed in on two components of transparency: visibility and inferability [24]. As expressed in Gregory Michener's recent review of efforts to capture transparency empirically: "The essential idea is that "transparent" information should be visible in the sense of being complete and easily accessible and inferable in the sense of lending itself to accurate conclusions" ( [25], 185; [24], 234). The stipulations of availability and accuracy are normatively compelling, perhaps even incontrovertible, yet still leave the definition quite vast. In Michener's later piece [25], in which he reviews and critically evaluates

\footnotetext{
${ }^{1}$ Policy organizations such as the World Trade Organizations can, of course, scarcely be criticized for advancing broad and sometimes conceptually vague definitions of policy concepts, definitions which may stretch to encompass both conditions seen as necessary for a policy measure to take root and operate effectively. Policy actors' main aim is to promote "thick" meaningful reform, not lay the groundwork for empirical measurement, an inherently more precise exercise which requires "thinner" conceptualizations.
} 
international transparency policy indexes (ITPIS) often used in the policy community, he instead advances a case for methodological pluralism and a need to examine the considerable variation among the various institutions in a single polity, a call with which we agree and which necessitates a more refined theoretical apparatus.

Taking this line of argumentation a step further, we advocate that the empirical study of transparency requires greater conceptual precision and, more importantly, operationalizations tailored to the situational specifics, in particular paying attention to the purpose for which information is to be used, as well as the intended users, i.e. the principals (government offices, voters, and non-state actors acting outside of electoral institutions). The purpose and principals require different types of information, with more involved principals generally needing more detailed and comprehensive information. What different purposes might transparency thus serve? The purposes of government transparency may be of three ilks: deliberation, predictability, and accountability. Starting with deliberation, i.e. column D Table 1, transparency in policy making allows, according to some normative theorists, for more extensive and meaningful participation in policy-making [26]. The availability of information in the input stage of the political process does not axiomatically lead to participation and deliberation (and too much openness may even impede deliberation under some circumstances, see [27, $28]$ ), but the disclosure of information to stakeholders in policy making is indisputably a precondition of successful deliberation.

In terms of predictability (column $\mathrm{C}$ Table 1), information regarding rules and regulations, as well as the implications for failure to comply with rules and regulations, have been pointed to as necessary preconditions of a stable investment climate, lowering risks in market transactions [5]. As with deliberation, this is not to say that fair and impartial implementation and enforcement of rules, i.e. rule of law, becomes folded into the definition of transparency, as rules may be equally well published in two settings but to varying degrees enforced consistently and impartially (c.f. [22], 14). In order to adequately test the merits of transparency empirically for investment behavior, it would thus be essential that the concept not stretch to include impartial enforcement of rules.

The third overarching purpose of transparency - and the one that brings us to the link to anti-corruption efforts - is accountability (columns A and B Table 1). Analogous to both deliberation and predictability, theoretical arguments that transparency constitutes a necessary precondition to accountability are highly compelling, yet here as well, the concept should not be stretched to include accountability in its entirety by including elements of sanctioning, or even the capacity and performance of agents (government agencies) more generally [20,29]. Accountability implies a number of components: 1) that an agent provides - routinely or upon demand - an account to principals regarding activities related to a specific domain, 2) that the agent justify/explain decisions and 3) that the principal has the authority and the means to sanction the agent effectively ( [20], 209). Transparency thus only refers to the first of these components. When measures of transparency incorporate additional components of accountability, empirical investigations may suggest that transparency is strongly associated with less corruption. Yet in the policy world, transparency measures refer only to access to information, and do not require answerability or sanctioning. Developing measures that better correspond to transparency as defined in policy circles is therefore necessary to understand whether, and under what conditions, government transparency leads to lower levels of corruption. 


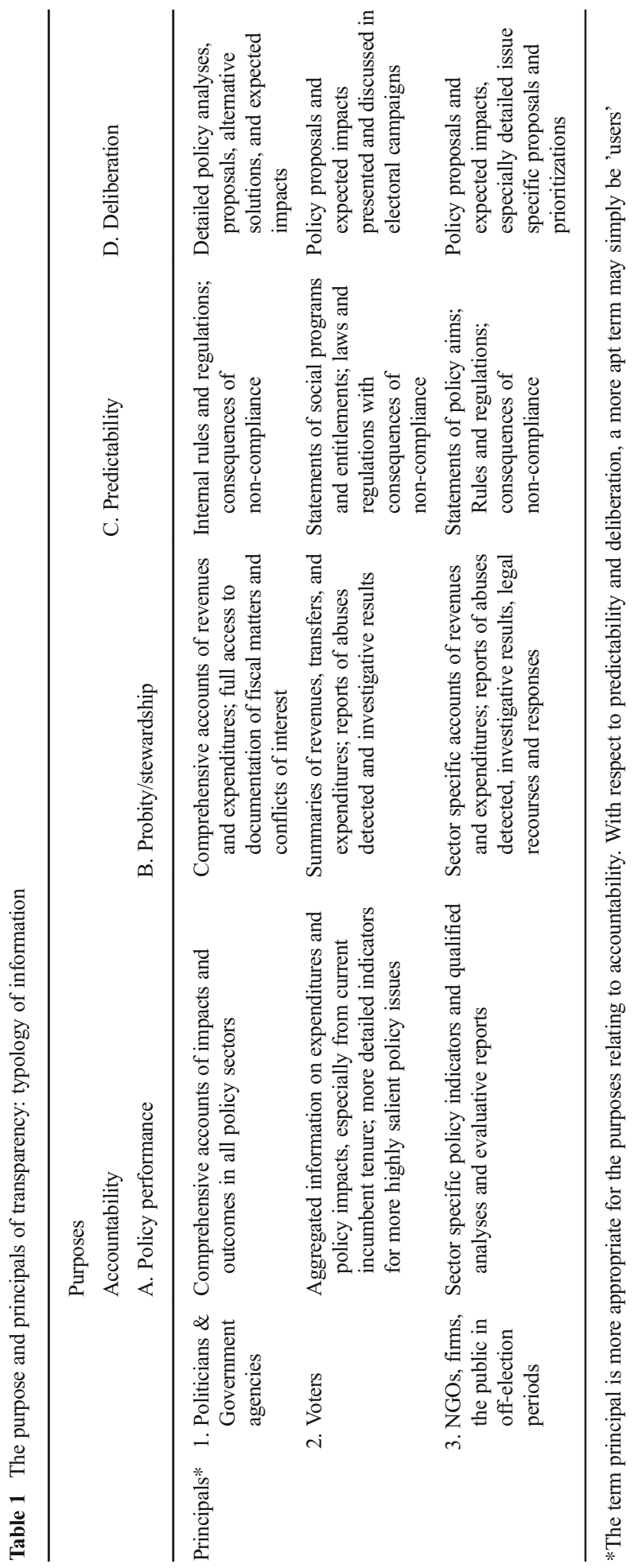


Transparency in various forms is hypothesized to enable several different forms of accountability, including horizontal (intra-governmental), vertical (electoral), and diagonal (societal). ${ }^{2}$ Each of these forms of accountability implies a distinct category of principals, but also may have two more specific, albeit interrelated, accountability functions (column A versus B Table 1). The first relates to policy performance, for which information regarding outcomes is the most relevant, and the other relating to the legal and ethical use of public power. Accountability for policy performance (column B) - which may be horizontal as when legislative assemblies take corrective action with respect to policy performance, but may also be vertical, as when the electorate votes retrospectively based on performance. Both require information on social and economic conditions detailed enough to track change.

Accountability exercised to ensure probity and honest stewardship of public resources (column B), our main focus and the type of transparency captured by the measures introduced below, requires information regarding, in particular, government finances, i.e. revenues, transfers and expenditures. Some of the more common and deleterious forms of corruption involve diverting or embezzling funds as well as requiring irregular payments for contracts or licenses, and the ability to track fiscal flows both into and out of public coffers is therefore a necessary precondition to detect such activity. In addition, mechanisms such as whistleblower protections further strengthen transparency with the purpose of exposing malfeasance and corruption in its various forms.

The second situational parameter which the operationalization of transparency ought to take into account, is, we argue, the intended principal(s). Several authors regard principals as an integral part of the definition of transparency, as in Kaufmann's [30] definition of transparency as the "increased flow of timely and reliable economic, social and political information, which is accessible to all relevant stakeholders" (see also [31]). Yet without stipulating the intended stakeholders, or principals, operationalizations of transparency may fail to take into account that information may be accessible to, for example, initiated experts but impenetrable to a lay audience. Moreover, bringing to light the issue of the intended principal uncovers another relevant parameter in the conceptualization of transparency as it relates to government corruption, namely the matter of who controls the flow of information and whether principals may request information, and not merely partake of the information that agents elect to publish. A government agency may for example publish information only very selectively, such as simple pie charts indicating revenues and expenditures, but also willingly open its books to formal auditors and the lay public alike upon request, while another may publish more information a priori but deny (by intent or omission) requests for additional documentation [17]. Measures that ignore this distinction risk overestimating the availability of useful information, as they reflect the volume of information and ignore actual utility for the intended purpose of information; agents may strategically abstain from publicizing information that may reveal malfeasance and culpability.

\footnotetext{
${ }^{2}$ Full and total exposure of all aspects of an organization's activities is theorized to ameliorate abuses mere through self-restraint (as implied in the oft-cited quote by Brandeis, that sunshine is the best disinfectant). Full and total exposure is, however, quite unrealistic, as any form of documentation invariably involves selection and abstraction, both of which allow an organization or its members to obscure aspects they wish to hide.
} 
In terms of transparency as it relates to constraining corruption, principals may include government offices - e.g. offices of internal oversight, elected assemblies, the judiciary - as well as non-state actors, i.e. citizens, civil society associations, and the media. In polities in which corruption is endemic, many government actors and institutions may be enmeshed in, and therefore gain from, the same self-serving behavior and disregard of rules which they are tasked with detecting and sanctioning in others. Where pervasive, in other words, corruption in all likelihood undermines government actors' incentives to hold one another accountable regardless of the availability of information, what Timothy Besley has termed the problem of the lack of a principled principal ( [32]; see also [33]). Many in the policy community have therefore pointed to non-state actors as the most plausible honest principals, as they have greater incentives to redress abuses. Although these claims rest on a number of strong assumptions about political reality [1, 18], the measure proposed here nonetheless seeks to capture the extent to which the public has access to information relevant to detecting venality.

The next section reviews some recent attempts to measure transparency and argues that many of them cast a wide net, tending to capture government transparency but also other attributes of government quality. If transparency is not measured distinctly from related concepts such as accountability, participation or state capacity, resulting measures are of limited use in investigating how transparency relates empirically to these other normative goods.

\section{Approaches to measurement}

Disentangling transparency from empirically and conceptually related phenomena, such as state capacity, accountability and participation is analytically feasible and necessary to understand the policy mechanisms and dynamics by which political systems reach and maintain higher levels of political development. While the distinction between transparency and accountability are discussed above, we now turn to distinguishing government transparency from state capacity. Collecting, compiling, computing and publishing reliable information in a timely manner requires a certain type and level of institutional capacity (along with political will), but state capacity extends far beyond this type and level. State capacity in its broadest sense extends well beyond the resources and competencies required to collect and organize information to include the entirety of government institutions involved in the collection of taxes, enforcement of laws, the protection of private property, and the provision of public goods and services, among other things (e.g. [34, 35]). Soifer [36], for example, delineates three dimensions of state capacity - coercive, fiscal and administrative and a government's ability to compile and publish relevant information would only rely on administrative capacity, and not even that dimension in its entirety. Capacity to track and report on societal conditions may well correlate with other aspects of state capacity, it does not necessarily always do so. Institutional capacity has been shown to vary considerably among state organizations, and it is therefore crucial to develop targeted measures of transparency that do not tap extensively into the aspects of state capacity not related to compiling and publishing information. Insum, measures that tap extensively into a state's capacity in a broad sense, or incorporate measures relating to accountability mechanisms or even citizens' confidence in government bodies, cannot 
be used to study the significance of transparency for other specific aspects of government performance without introducing risk of false positives, or type I errors [25].

Although long overlooked in cross country empirical research, and in particular when compared to the groundswell of research efforts devoted to understanding and measuring corruption, recent years have seen several important and helpful attempts to capture the concept of transparency empirically. Studies of the effects of transparency have employed several approaches to measurement: composite indices comprising a broad spectrum of indicators, where some extend conceptually beyond transparency [23, 70]; specific indicators of transparency such as expert assessments of legal frameworks, or surveys of governments' publication of relevant information and statistics or proxy measurements, such as press freedom [37] or newspaper circulation [15, 38]. While media freedom is a requisite condition for the circulation of information relevant to scrutinizing government, measures of media freedom do not relate directly to government and its operations, and therefore tap into contextual factors outside the realm of the state. These will therefore not be discussed further here. Composite indices are, however, currently the best available option for measuring government transparency, and a more detailed discussion of their strengths and weaknesses is therefore warranted.

Composite indices of transparency build on the basis of a wide range of data sources and, using a similar logic to the widely used indices of corruption and governance such as the World Bank's Governance Indicators or Transparency International's Corruption Perception Index, include indicators that use a plurality of definitions of transparency and data collection strategies. Williams [70] brings together data from 29 sources and derives annual scores for 1980 through 2010 for 190 countries. Similarly, although available for one year only, Bellver and Kaufmann [23] build transparency indices on 13 surveys carried out in 2003 and 2004 by various international organizations and nonprofit organizations.

Finally, broad composite indicators risk missing the important distinctions among trees in efforts to depict the entire forest. As Michener ([25], 184), indices are generally not guided by policy theories regarding which aspects of the phenomenon being measured are crucial versus which may simply improve government in a general normative sense. He writes: "indexes presuppose substitutability while policies contain non-substitutable 'necessary' policy provisions", suggesting that "policies can rank favorably on indexes notwithstanding the absence of lynchpin policy provisions." Scheppele [39] makes a similar point with respect to rule of law indicators, which may rate states on component parts, even if those components add up to a Frankenstate which does not at all embody and assure rule of law. Aggregate scores may therefore reflect how well a state ticks a number of boxes considered favorable without regard to which features are crucial and which are less essential. In other words, broad indices may capture more than government transparency itself, but in doing so may blur and thus fail to capture the actual variation relevant to exploring the empirical questions at hand. ${ }^{3}$ These points suggest a need for measures to be attentive to the de facto condition under study, and not merely aggregating legal or circumstantial indicators.

\footnotetext{
${ }^{3}$ Michener [25] is particularly interested in international transparency policy indicators, i.e. "policies that are centrally concerned with transparency (transparency as an end), which include freedom of information laws and open-data regulations; and transparency provisions that form part of broader legislation or administrative directives (transparency as a means), such as campaign finance disclosure or budgetary transparency”.
} 
Several measures of government transparency have indeed sought to narrow the scope of indicators and focus on the actual release and flow of data and information from government officials ( $[16,40,41])$. Data availability indicators refer to surveys of government information published (primarily) electronically, or data reported to international organizations (see also [3]). Most notable among these is perhaps the index developed by Hollyer et al. [16] which maps the extent to which states comply with requests from the World Bank to release indicators that together make up the World Development Indicator (WDIs). While a significant contribution in its own right, and certainly an important indication of a state's ability to collect and willingness to release data, the Hollyer et al. (henceforth HRV) indicator is not entirely suited to exploring the link between transparency and corruption for two reasons. First the HRV-index does not necessarily capture whether the government publishes information that can allow citizens to detect abuses. The indicators included in the WDI span a wide range of policy areas as well as economic conditions and from a range of market spheres. ${ }^{4}$ Second, given the extensive span and the high-resolution nature of the indicators included in the WDI, it is likely that the HRV-index taps not only into a state's willingness to collect and publish statistics, but its ability to do so in a broad range of policy sectors, and hence into government capacity. Tracking and measuring such a range of conditions presumes effective state presence in virtually all spheres of society. While useful for examining the link between government openness and phenomena that are exogenous to the state - such as for example aid donors' willingness to allocate funds to a country - these broad transparency indicators are less useful for understanding the link between transparency and phenomena endogenous to government operations.

Our conceptualization and measurement of transparency seek to take these challenges into account in order to lay the groundwork for investigating more fine-grained theoretical claims. It specifies both the purpose and the principals and thus uses a narrower and more theoretically founded definition and measurement of transparency. It focuses specifically on the necessary and de facto elements of transparency for detecting government abuses, such as whistle blower protection, and the ability of actors outside the government to attain the information needed to assess performance. Although expert judgments are subject to problems of their own [42], they offer the advantage that they capture not only de jure but also de facto conditions. ${ }^{5}$

\footnotetext{
${ }^{4} 47$ statistical indicators deal with imports and exports; 64 with the economic situation in the country including employment indicators; 45 indicators related to societal conditions such as enrollment rates but also area and population, the remaining indicators related to natural resources (both production and consumption) or with infrastructure. Only 14 of the approximately 230 statistical indicators requested by international organizations relate to government revenues and expenditures.

5 Treisman [42] notes that expert surveys of corruption are subject to a number of problems, including a Western bias and a tendency to infer the existence of corruption from the overall well-being of a country. The large majority of public administration experts who participated in the QoG expert survey were from the country for which they provided asseessments. Moreover, assessing government transparency (and lack thereof) involves less conjecture than assessing the prevalence of corruption, as the latter is clandestine and the availability, or absence, of information is more apparent.
} 


\section{Transparency for government probity: Fiscal openness and exposure of abuses}

The conceptualization and measure of transparency for government probity introduced here capture two main dimensions of transparency argued to be relevant to containing and curbing corruption: fiscal openness and likelihood of exposure of abuses. These two aspects in combination capture the extent to which the public has access to information relevant to detecting venality. Fiscal openness is defined as the information that the government releases, electronically or in other forms, needed to track the flow of revenues and expenditures. It encompasses both the extent to which citizens can demand and receive information not published proactively, as well as that published routinely by government.

The Quality of Government expert survey included two questions designed to capture this dimension of transparency, the first asking experts to evaluate whether citizens and media actors can track the flow of government revenues and expenditures in their country. A second question asked experts to rate whether government documents and records are open to public access.

The second dimension, likelihood of exposure of abuses, depends primarily on the ability and willingness of actors inside the government to report any abuses they witness, which is largely a function of the whistleblowing protections in place. Whistle blowing in the public sector has, compared to transparency more generally, primarily been studied by legal scholars. Miceli and Near [43] define whistle blowing as "the disclosure by organization members (former or current) of illegal, immoral or illegitimate practices under the control of their employers, to persons or organizations that may be able to effect action" (see also [44-46]). Whistle-blower protections allow individuals to disclose information despite their individual connection to, and vulnerability to retaliation from, those in higher positions of power.

Specific whistleblower protection laws have been established in over 30 countries, while in other countries whistleblower protection is regulated through labor laws and laws related to public sector employment. These legal provisions vary in the extent to which they discourage the release of information to external actors (the media), whether they stipulate rewards for exposing abuses and whether protection from retaliation is circumscribed if it is deemed that whistle-blowers did not act in good faith [47]. The countries that have adopted more comprehensive whistleblower protection laws include the UK, South Africa, Ghana, Canada, Japan, New Zealand, and the United States [48, 49]. Sweden also has strong protections, granted through the world's oldest freedom of press act, which give civil servants the right to anonymously report misdeeds in the public sector, and prohibit journalists from revealing the identity of sources under penalty of law. The survey asked experts to evaluate the overall likelihood that civil servants would experience negative repercussions if they engaged in whistle blowing.

\section{Analytical approach and data}

The empirical analyses seek to determine whether there is a link between transparency and corruption independent of other institutions or attributes of government and societal conditions. A correlation with corruption suggests convergent validity of the measure, and 
the fact that the correlation is independent of other factors indicates that we are capturing something that is distinct from the efficiency and capacity of the state more generally, i.e. divergent validity [50]. Since we believe that existing measures of transparency may partly capture state attributes outside the conceptual scope of transparency, we argue that evidence is still lacking as to whether an independent association exists. It is plausible that any observed association between transparency measures and government corruption may be due to the broad scope of measures used to measure both of these, which might result in false positives. Alternately, however, it is possible that existing measures are so noisy as to obscure a true association. Measures of transparency that tap into attributes of the state other than transparency may actually fail to capture the more relevant and operative aspects of transparency for reducing corruption, and a true association may become undetectable once these are controlled for. The analyses therefore examine the link between the measure we propose here and various measures of corruption, first in bivariate analyses and then under control for attributes of the state and society into which broader transparency measures may tap. The models taken together thus aim to examine whether transparency is linked to corruption independent of other factors.

The data are collected through a global survey of public administration experts, carried out in 2014. In addition to measuring our concept of transparency, the survey includes 59 additional questions on a range of topics related to bureaucratic quality, autonomy and the functioning of the state. Experts were identified by contacting public administration organizations affiliated with the United Nations Public Administration Network, professional networks, the academic literature and university websites. 7096 were sent the link to the questionnaire, of which 1294 , or $18.2 \%$ submitted completed responses. The mean number of respondents per country in the dataset is 8.1 but some have as few as one expert. Only countries with at least 3 expert responses are included in the analyses below. One of the main concerns with expert surveys is individual level bias. An evaluative review of the data has analyzed individual level variation in experts' assessments and concludes that “...estimates for a particular country are not determined by the make-up of the group of experts who provided assessments" [51]. ${ }^{6}$

The survey included three questions, combined into a transparency index capturing the dimensions of transparency discussed above. Experts were asked to rate to what extent they feel the following statements - the first two of which relate to fiscal openness, the third to the likelihood of exposure of abuses - applied to the country in question $(1=\text { not at all; } 7=\text { to a very large extent })^{7}$ :

- Citizens and media actors can track the flow of government revenues and expenditures

- Government documents and records are open to public access

\footnotetext{
$\overline{6}$ They also enclose a more detailed discussion on standard deviations and respondents perception bias.

${ }^{7}$ In our measure of whistle blower protection we elect to let the respondents interpret what they would consider to be an "abuse of power", since the interpretation may vary across contexts, depending on norms etc. While this may differ in severity across contexts, we cannot model this directly and thus in our model we assume that the cultural interpretations are more or less constant within, but not across, countries. The two dimensions of government openness are highly correlated (.88), while their correlation with the level of whistleblower protection is, as expected, .53 and .52 respectively. The alpha of our index is .85 .
} 
- Public sector employees risk severe negative consequences if they pass on information about abuses of public power to the media

In the empirical analyses all values are coded so that higher values mean more transparency.

Figures 1 and 2 show the transparency scores for OECD and non-OECD countries respectively. The country scores for the two component indicators shown in figures A1-A4 in the Appendix. Wicpossibility of tracking fiscal flows, the estimates plotted in the figures seem plausible. Many of the countries that cluster in the upper end of the transparency scale have long-standing traditions of transparency (Sweden, Finland, Iceland) or have recently taken large steps towards increasing their level of transparency (Chile and Costa Rica). Chile's access to information law surpasses international standards in terms of the strength of legal guarantees and protections offered to citizens, suggesting a normative climate of transparency and openness. At the other end of the transparency scale, countries such as Japan, Guatemala, Eritrea, Algeria or Zimbabwe rank among the lowest of all the countries in the sample.

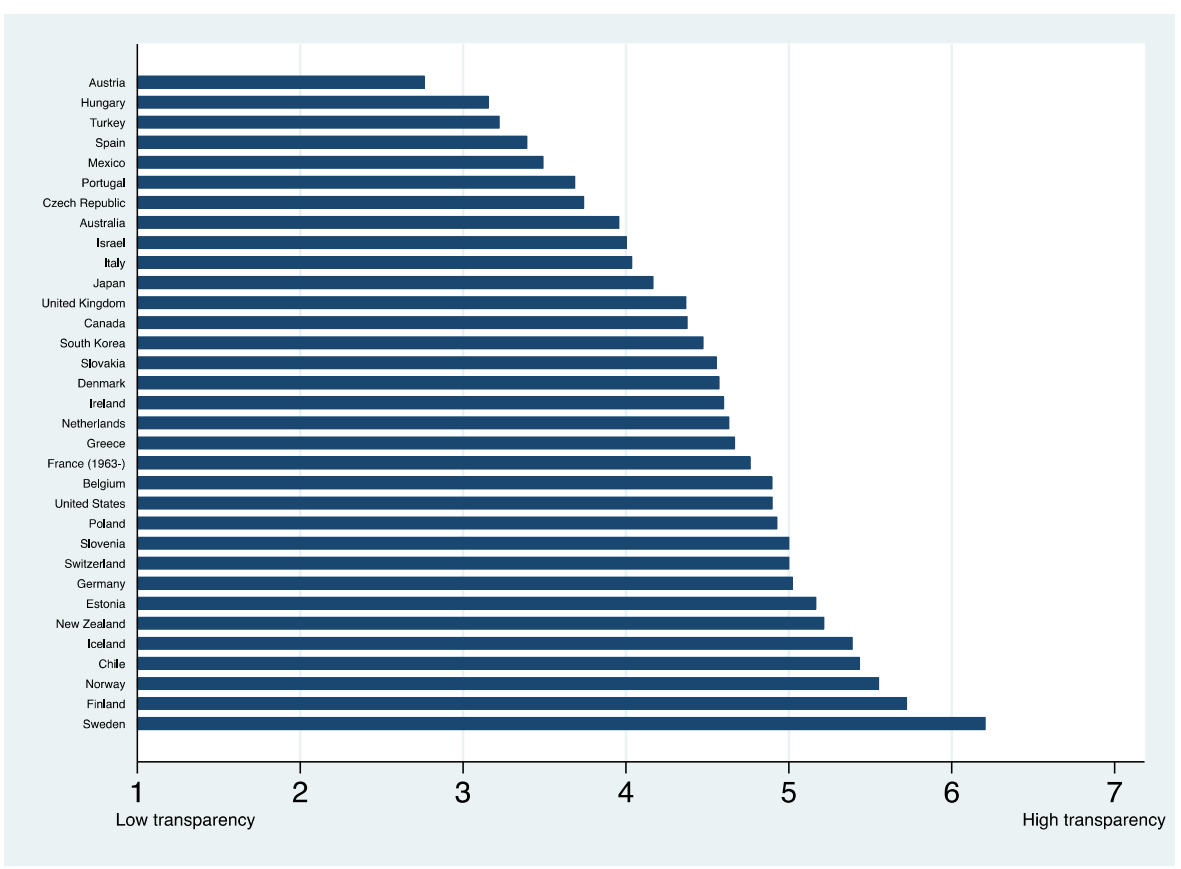

Fig. 1 Transparency scores for OECD countries 


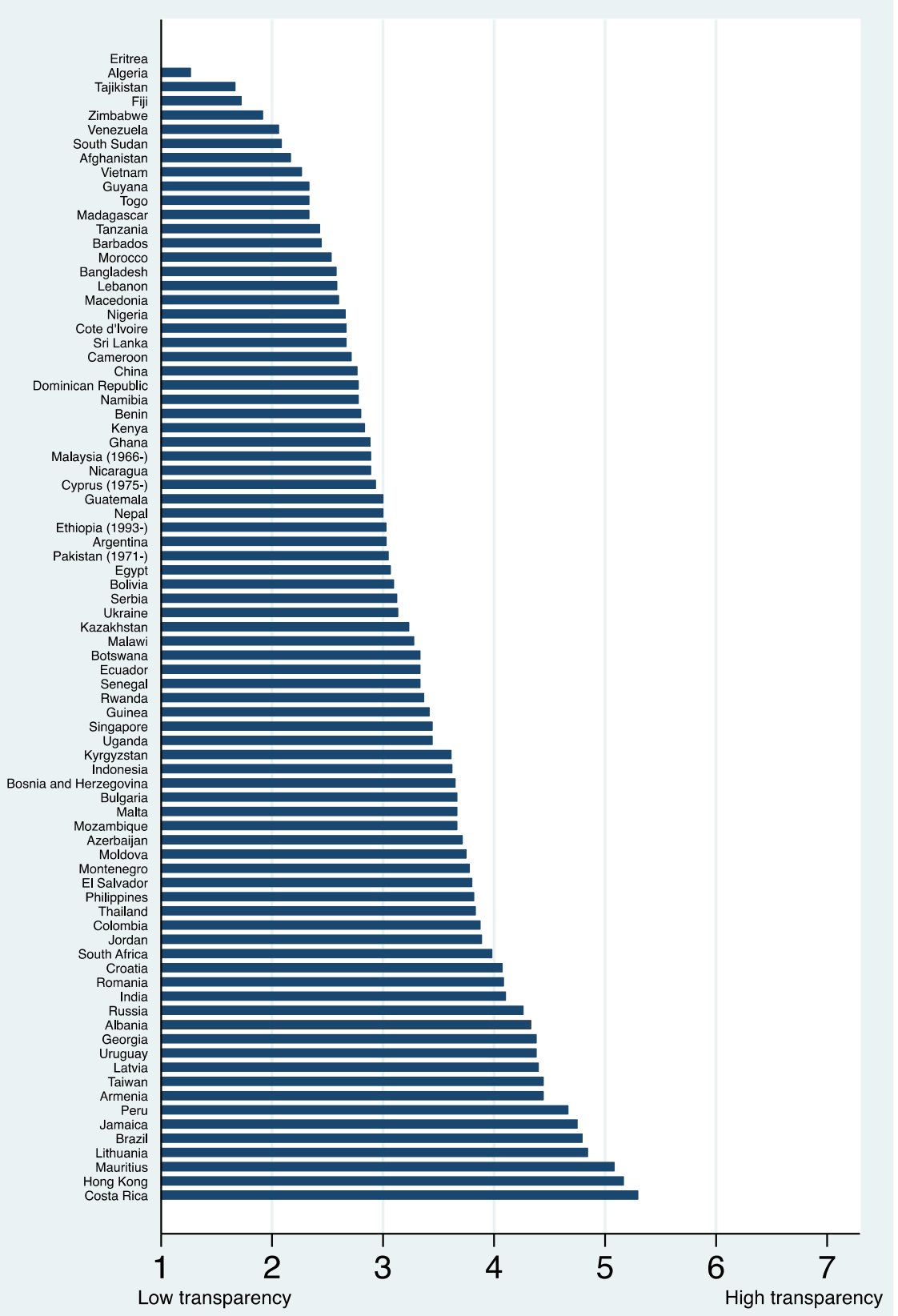

Fig. 2 Transparency scores for non-OECD countries 
We compare the association of our measure of transparency to a variety of corruption measures, to that of two significant recent attempts to measure transparency: The HRV index [16] and Williams' [70] measure of information transparency. Hollyer et al. [16] measures governments collection and release of economic and societal data, and relies on a Bayesian item response (IRT) model, which treats transparency as a latent predictor of the reporting or non-reporting of data in the World Bank's World Development Indicators (WDI) data series, including 240 variables collected by the WDI over time. The resulting index contains 125 countries covering a period from 1980 to $2010 .^{8}$ Williams' index of information transparency [70] covers the same time span but uses data from 29 sources, with scores being derived for more than 190 countries. The component indicators capture the quantity of economic, social and financial information (very similar to the HRV-index), as well as the quality and processes generating economic, financial and social data, and information infrastructure. ${ }^{9}$

\section{Corruption measures}

The corruption measures used range from narrow to broad narrow and broad, with the narrow measures capturing two distinct forms of corruption: petty (bribepaying) and grand (irregular payments and diversion of funds). The former builds on the 8 questions from Transparency International's Global Corruption Barometer (GCB) regarding whether or not a surveyed member of the public or someone in their household has paid a bribe in the past 12 months for various services. These questions are combined with one question from the World Economic Forum's (WEF) Executive Opinion Survey, which asks executives how common it is that firms have to make irregular payments. ${ }^{10}$ The measure of grand corruption also builds on two measures from the World Economic Forum's Executive Opinion Survey that capture whether government shows favoritism when granting contracts, and the prevalence with which officials divert public funds to companies, individuals, or groups due to corruption [52]. We also examine whether transparency measures relate to a broad and widely used measure of corruption, namely the World Bank's control of corruption measure. ${ }^{11}$

\footnotetext{
${ }^{8}$ This measure has been used in several recent studies examining the link between government transparency and democracy, and regime stability [70, 71].

${ }^{9}$ Williams offers a second indicator denoted as "accountability transparency". This measure includes measures of human rights and executive constraints, making it inordinately broad. Since there is a rather close relationship between accountability transparency and accountability or democracy more generally (Williams accountability transparency is correlated at .91 to the Freedom house polity 2 measure of democracy in 2014), we believe that Williams' measure of information transparency is a stronger indicator of transparency per se.

${ }^{10}$ The Global Corruption Barometer questions refer to customs, education, judiciary, land services, medical services, registry and permit services, police or tax authorities. The World Economic Forum measure: "In your country, how common is it for firms to make undocumented extra payments or bribes connected with (a) imports and exports; (b) public utilities; (c) annual tax payments; (d) awarding of public contracts and licenses; (e) obtaining favorable judicial decisions. In each case, the answer ranges from 1 (very common) to 7 (never occurs)" [53].

${ }^{11}$ The World Bank Governance Indicators are also strongly associated to the ICRG measure of corruption as well as the Transparency International's Corruption Perception index.
} 


\section{Control variables}

In our analysis, we explore the association between transparency and corruption under control for confounding factors to determine if an association exists independent of a country's overall level of political development. We therefore control for democracy and bureaucratic quality in order to capture the related phenomena of accountability (including participation) and state capacity. To capture the level of state capacity we use the International Country Risk Guide (ICRG) indicator of Bureaucratic Quality, which rates the extent to which government bureaucracies are autonomous from political pressure and recruit professional and qualified personnel to the civil service. These aspects of bureaucratic quality have been shown to correlate very strongly with the ability of the state to deliver services in a broad range of areas as well as the state's ability to compile and publish statistics [54]. To capture democracy, we use the Boix et al. [55] dichotomous measure, which classifies countries as democracies if they hold free and fair elections and satisfy a threshold level of suffrage. ${ }^{12}$

The analyses also control for indicators of of modernization or development such as GDP/capita (a logged measure from the Gleiditch Expanded Trade and GDP Data, [56]) and education (UNESCO gross enrollment data). The high correlation between government quality and economic development is, according to Treisman [42] "by far the strongest and most consistent finding" in empirical work (see also [42, 57, 58]). We also control for ethnic fractionalization using the measure developed by Alesina et al. [59], since more polarized societies are more prone to competitive rent seeking ( [60-62]: [63]) which may affect the quality of government institutions. Finally, the number of women in government may tap into both concepts since it may indicate a general inclusiveness of the political system [64-66].

\section{Results}

In this section we evaluate the utility of different conceptualizations and measurements of transparency for exploring the association between transparency for corruption mitigation. Numerous studies suggest that transparency is associated with lower levels of corruption; ([3, 6, 13, 17, 30, 33, 67-69]), yet we have argued that the measures of transparency used may yield misleading results.

Tables 2 and 3 show the link between three different measures of transparency, our own as well as those advanced by Williams' [70] and Hollyer et al. [16]

\footnotetext{
${ }^{12}$ In order to ensure that our results are not influenced by the fact that we use a rather "thin" or dichotomous measure of democracy we have also rerun our analysis using the V-Dem polyarchy index [71] using a broader measure of democracy inspired by Dahls $(1971 ; 89 ; 98)$ notion of polyarchy (and including measures of "Elected officials", "Free and fair elections", "Freedom of expression", "Associational autonomy" and "Inclusive citizenship"). We find very similar results using this broader measure of democracy. We elect, however, to keep our thinner notion of democracy for the purposes of this paper,
} 


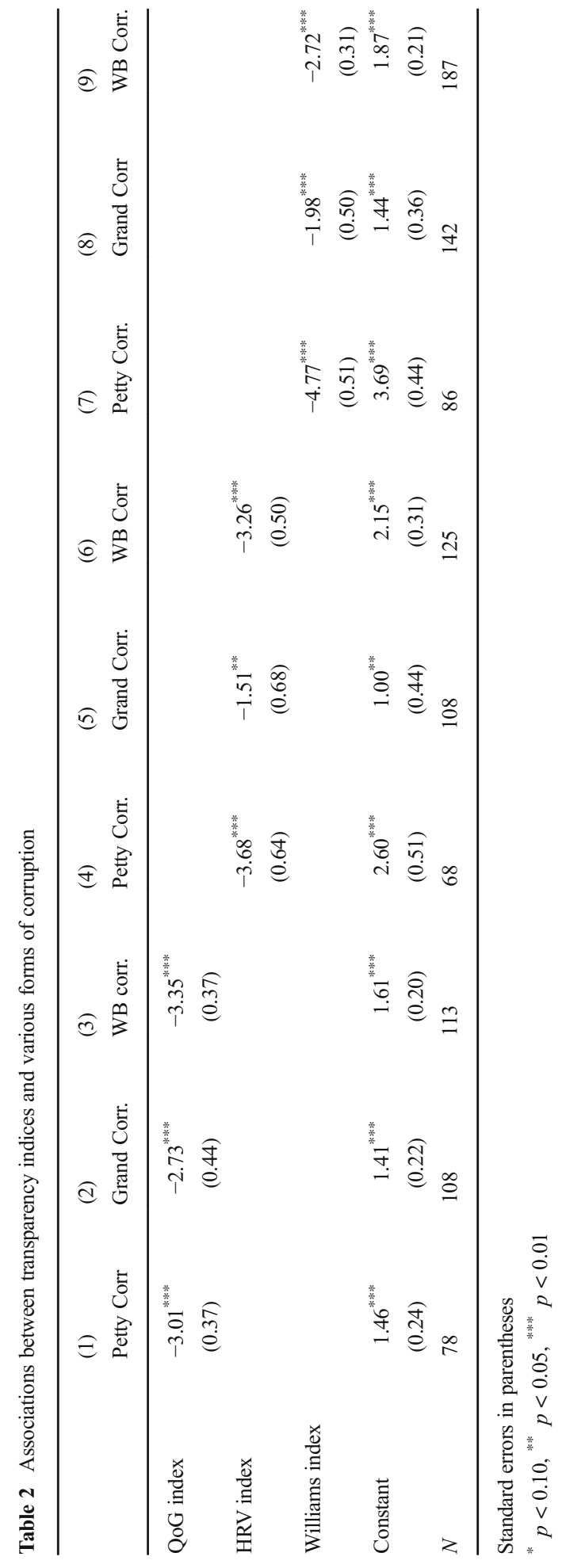




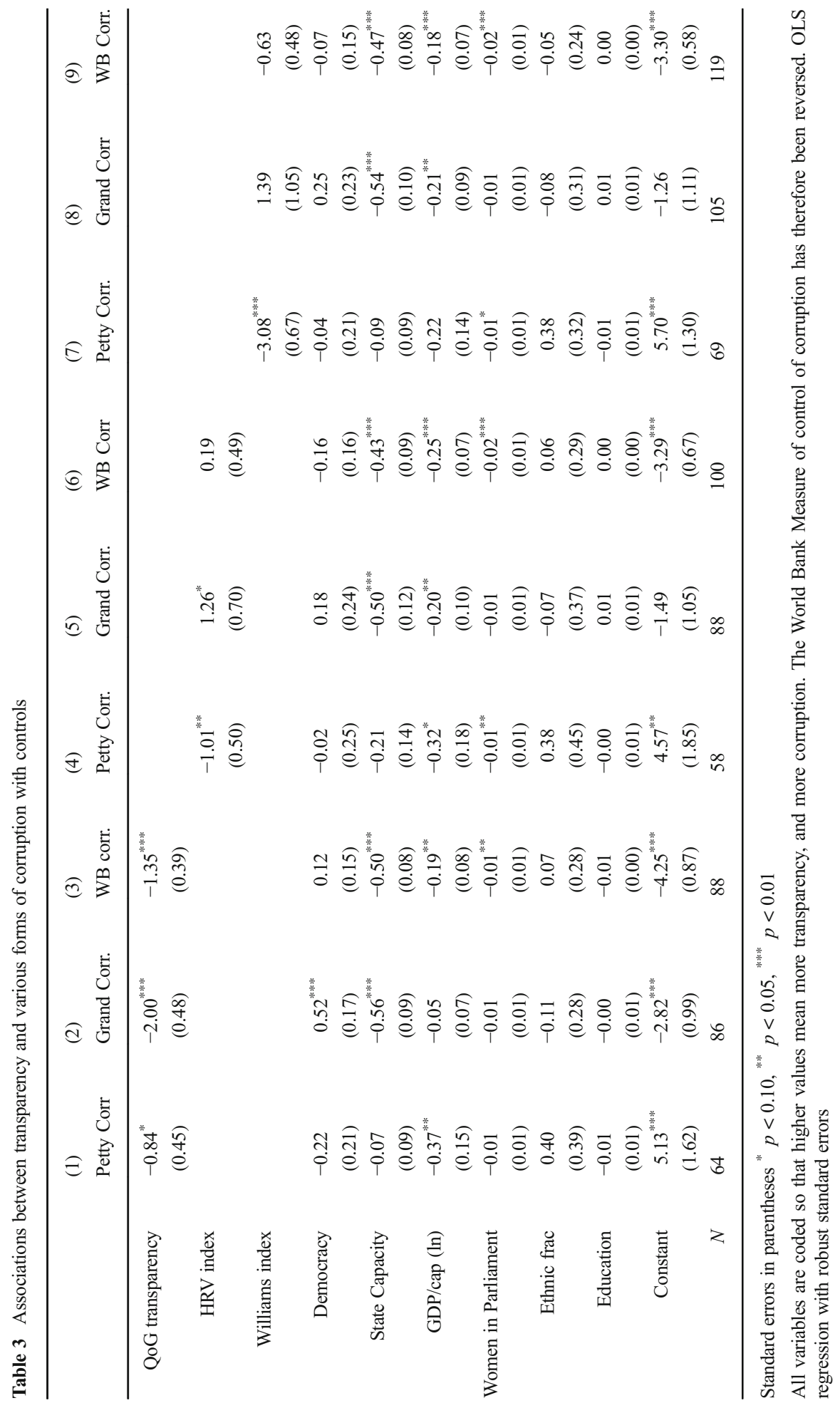


respectively, with three different measures of corruption. Table 2 shows the associations without controls and Table 3 with controls. All of the transparency measures have been rescaled to range from 0 to 1 so that the estimates show the total effect of each.

The three measures of corruption capture petty, grand and the World Bank's measure of control of corruption (inverted), an aggregate index on overall levels of corruption. The models without controls (Table 2) reveal that all of the transparency measures correlate with all of three corruption measures, and that the total effects do not differ substantially depending on which transparency measure is used. Once controls are entered into the model, however, the association between transparency and corruption does indeed vary depending on the indicator of transparency used (Table 3). Model 1 shows that the QoG transparency index is significantly negatively associated with the extent to which citizens' and business executives pay bribes to government institutions. Model 2 shows that QoG transparency is also negatively associated with grand corruption, defined as collusion among elites that involves major public sector projects, procurement and large financial benefits ([33]: 27). Thus the QoG measure of transparency is negatively associated with both petty and grand corruption, and regardless of whether measures are based on elites and ordinary citizens' self reported experiences or perceptions. Model 3 shows that QoG transparency is also negatively associated with the World Bank's corruption index that captures aggregate levels of corruption using a large number of component indicators. While the estimates are considerably weaker with controls in the models, the estimates remain statistically significant, suggesting that our measure of government transparency indeed does have an independent association with corruption.

Comparing the first three models with the remaining six lends some credence to our claims that existing measures of transparency may tap into attributes of the state that extend beyond transparency itself. Models 4-6 show that the association between the HRV index and petty corruption is negative, but is instead positive with grand corruption with controls in the model. The association with the control of corruption is not significant. While the HRV transparency index captures data that is relevant for demands for accountability or the functioning of democracy, this form of transparency may not lend itself as well to the detection of corruption in the management of public resources. Thus, even if data availability on market and societal conditions in general may be a function of democracy that also facilitates accountability, it may not suffice to detect corruption or the extraction of rents, which could remain relatively hidden even among widely published statistics. Models 7-9 show that the Williams' information transparency index is negatively associated with petty corruption, but is not associated with the other measures of corruption when controls are included.

In addition, the results also show that the level of democracy is generally insignificant when accounting for the effect of transparency. GDP/capita, share of women in the lower house and the level of state capacity are in almost all the models significantly negatively associated with corruption. 
Taken together, the results suggest that the association between transparency and corruption is not stable across indicators, and that the association between transparency and corruption may be contingent upon the extent to which these measures tap into political development and state capacity more generally. Our results suggest that the QoG transparency indicator is more consistently associated with the different types of corruption included than other indicators developed and used in recent research.

\section{Conclusions}

Transparency, despite a surge of attention in policy and academic arenas, has received insufficient rigorous theoretical attention and has suffered from considerable conceptual stretching. Indicators agglomerated into indexes tend to be drawn from disparate areas and incorporate contiguous concepts such as accountability and underlying qualities of good government and state capacity. Much like concepts such as democracy or good governance, transparency is often discussed in conjunction with a host of attributes considered integral to good government, so much so that they are seldom disaggregated theoretically and empirically. A transparent organization is not by definition subject to strong sanctioning mechanisms, nor by necessity invites constituents or stakeholders to participate, provide input, and express grievances. A first step in the analytical dissection of transparency is therefore to disentangle it from other complementary aspects of good governance, as well as from the societal preconditions that shape whether transparency has the expected positive effects.

In investigations of transparency, using broad measures characterized by conceptual dispersion in all likelihood will result in false positives (type I errors), because measures bleed conceptually into one another. Alternatively, a measure which fails to capture the most relevant and operative aspects of a phenomenon may fail to reveal an associations which in reality exists.

This paper has sought to contribute a general theoretical framework that might assist in developing measures of transparency suited to exploring more specific claims about these positive effects, an exercise which, we argue, requires paying attention to the intended use or purpose of the information, as well as the intended user, or principal. Moreover, the paper introduces new data covering 105 countries and an index that captures the type of transparency likely to contribute to the control of corruption. The empirical analyses suggest that transparency indeed does have a robust and independent association with various forms of corruption.

Moving forward, we see a need for more in depth explorations of heterogeneity of the effects of transparency on corruption, either using the measure presented here or other more fine-grained measures. Previous research, including our own, has presented evidence that transparency in contexts with high levels of corruption can breed political resignation, especially if the mechanisms for exercising accountability are weak or lacking $[1,12,29]$, and that the likelihood of exposure may vary between different forms of corruption [72]. More research is needed on the contextual conditions needed for transparency to reduce corruption. 


\section{Appendix}

Table 4 Correlations

\begin{tabular}{|c|c|c|c|c|c|c|c|}
\hline & $\begin{array}{l}\text { QoG } \\
\text { Transp }\end{array}$ & $\begin{array}{l}\text { HRV } \\
\text { transp }\end{array}$ & W. tranp & Petty corr. & Grand corr & WB corr & Dem \\
\hline QoG transp & 1 & & & & & & \\
\hline HRV transp & $0.481^{* * * *}$ & 1 & & & & & \\
\hline W. transp & $0.697^{* * * *}$ & $0.775^{* * *}$ & 1 & & & & \\
\hline Petty Corr & $-0.616^{* * *}$ & $-0.546^{* * *}$ & $-0.771^{\text {**** }}$ & 1 & & & \\
\hline Grand corr & $-0.515^{* * *}$ & $-0.226^{*}$ & $-0.336^{* * *}$ & $0.498^{* * *}$ & 1 & & \\
\hline WB Corr. & $-0.629^{\text {**** }}$ & $-0.495^{* * * *}$ & $-0.568^{\text {**** }}$ & $0.721^{* * * *}$ & $0.814^{* * *}$ & 1 & \\
\hline Dem. & $0.534^{* * *}$ & $0.507^{* * * *}$ & $0.412^{\text {**** }}$ & $-0.397^{* * * *}$ & -0.0730 & $-0.429^{* * * *}$ & 1 \\
\hline $\mathrm{GDP} / \mathrm{c}$ & $0.576^{* * *}$ & $0.605^{* * *}$ & $0.613^{* * *}$ & $-0.788^{* * * *}$ & $-0.548^{* * *}$ & $-0.688^{* * *}$ & $0.273^{* * *}$ \\
\hline Women in parl. & $0.281^{* *}$ & $0.216^{*}$ & $0.318^{\text {**** }}$ & $-0.310^{* *}$ & $-0.300^{* * *}$ & $-0.337^{* * * *}$ & $0.154^{*}$ \\
\hline State capacity & $0.550^{* * *}$ & $0.486^{* * *}$ & $0.684^{\text {**** }}$ & $-0.745^{* * * *}$ & $-0.626^{* * *}$ & $-0.808^{* * *}$ & $0.466^{* * *}$ \\
\hline Ethnic frac. & $-0.401^{\text {***** }}$ & $-0.493^{* * * *}$ & $-0.252^{\text {***** }}$ & $0.485^{\text {**** }}$ & $0.238^{* * *}$ & $0.377^{* * * *}$ & $-0.283^{* * *}$ \\
\hline Edu & -0.00870 & -0.0714 & -0.105 & $0.261^{*}$ & 0.0781 & 0.0648 & 0.0527 \\
\hline$N$ & 196 & & & & & & \\
\hline
\end{tabular}

$\begin{array}{llll}\text { GDP/c } & \text { Women in parl. } & \text { State cap. } & \text { Ethnic frac. }\end{array}$

QoG transp

HRV transp

W. transp

Petty Corr

Grand corr

WB Corr.

Dem.

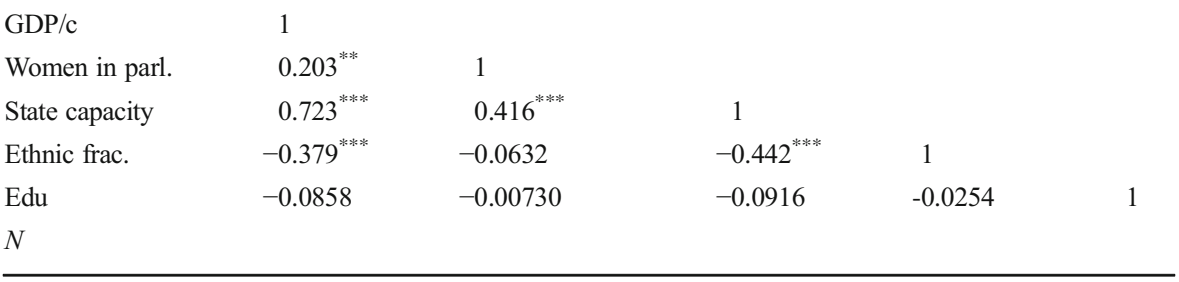

$t$ statistics in parentheses

${ }^{*} p<0.05,{ }^{* *} p<0.01,{ }^{* * * *} p<0.001$ 


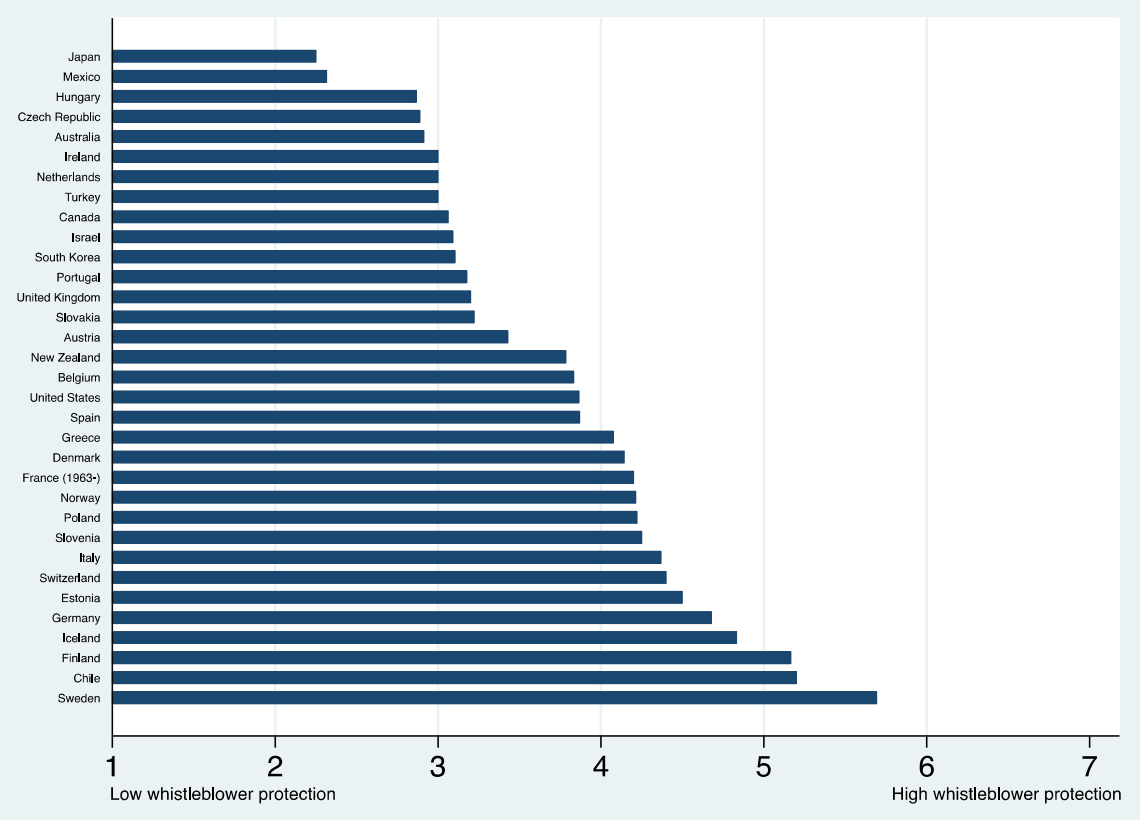

Fig. 3 Whistleblower protection in OECD countries 


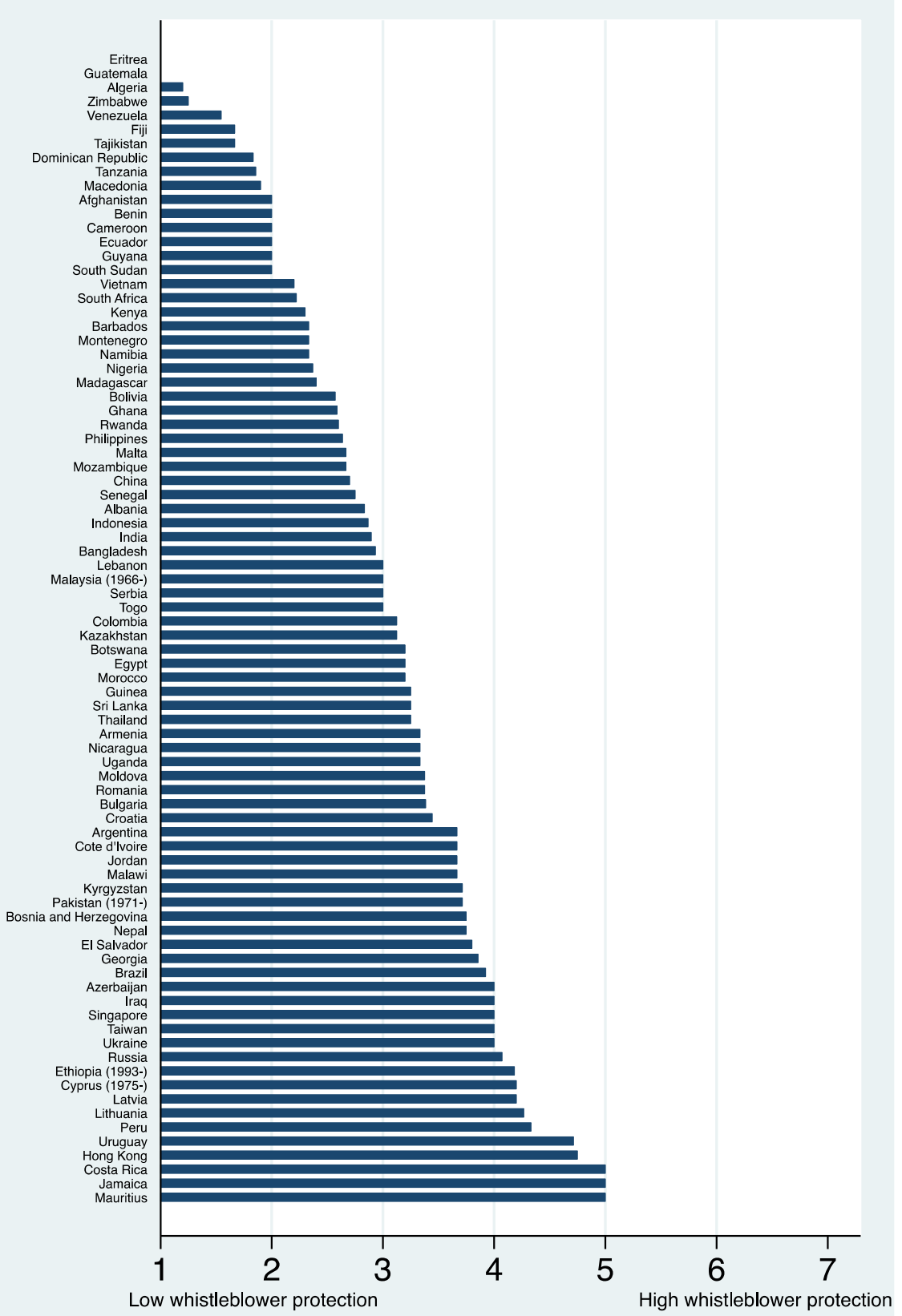

Fig. 4 Whistleblower protection in non OECD countries 


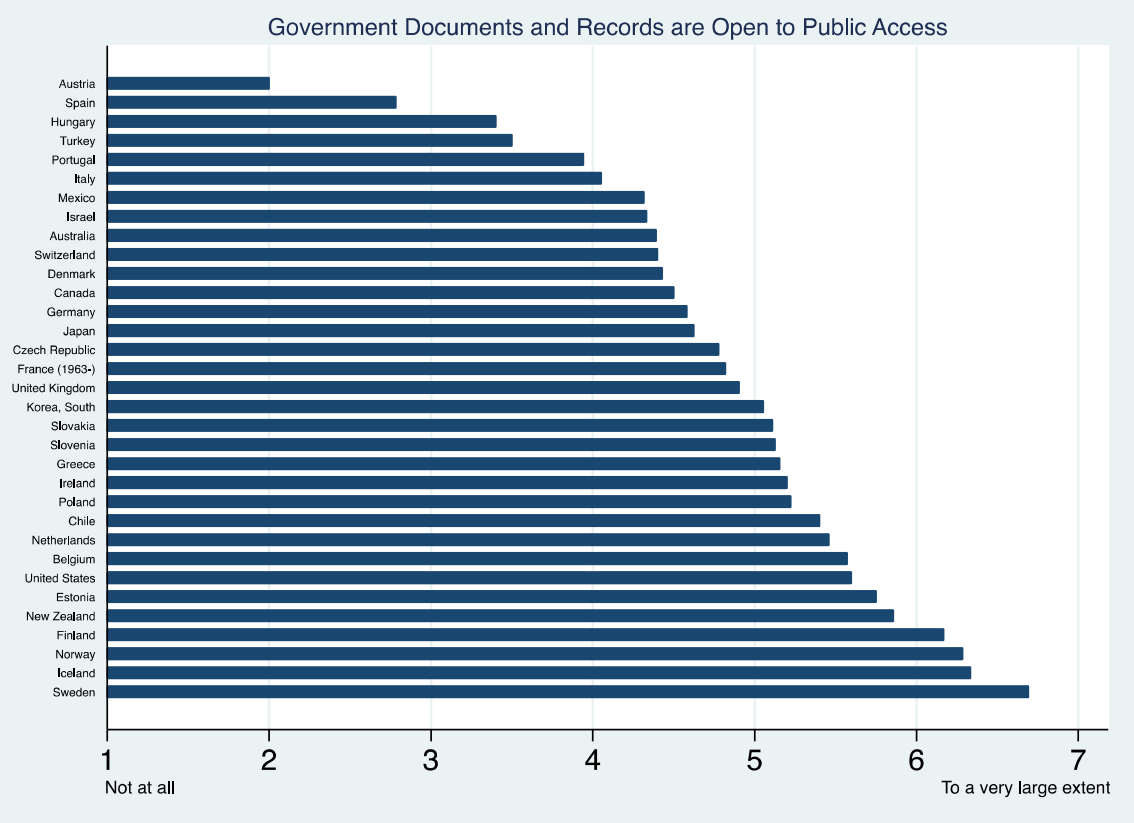

Fig. 5 Government openness in OECD countries

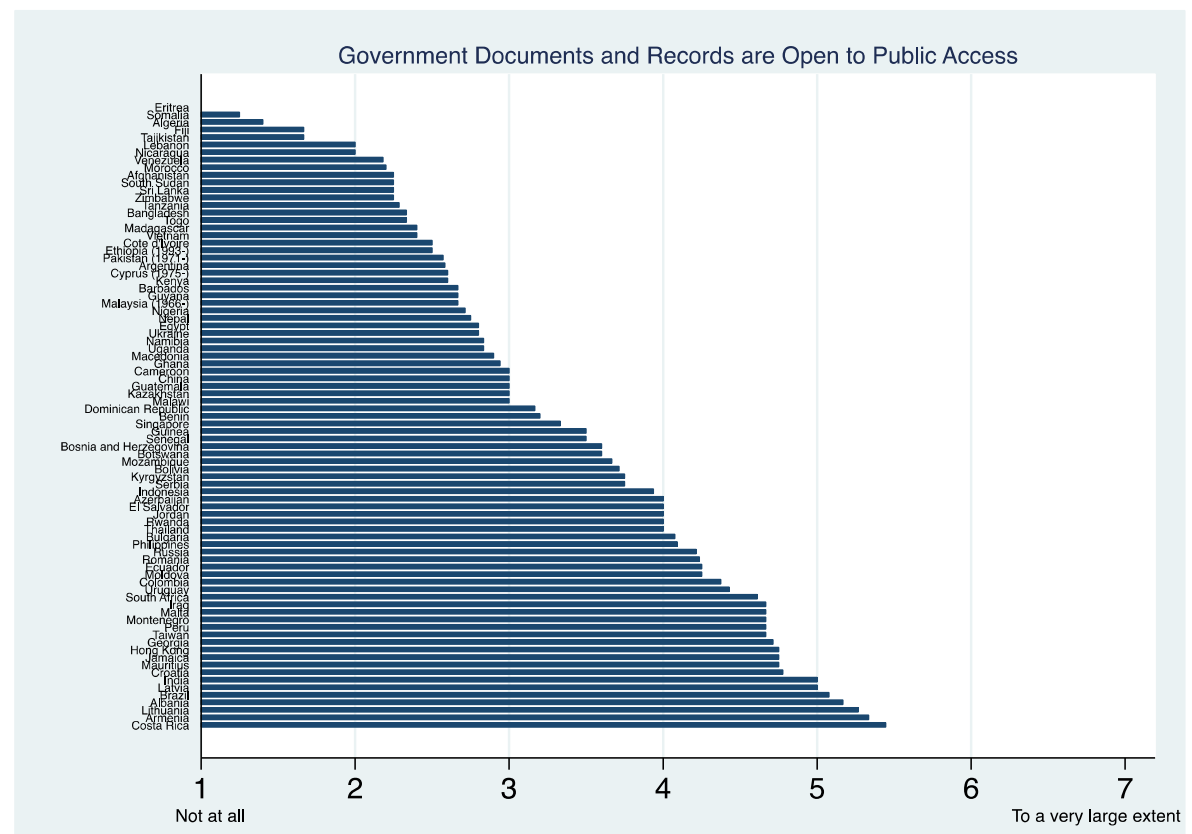

Fig. 6 Government openness in non OECD countries 


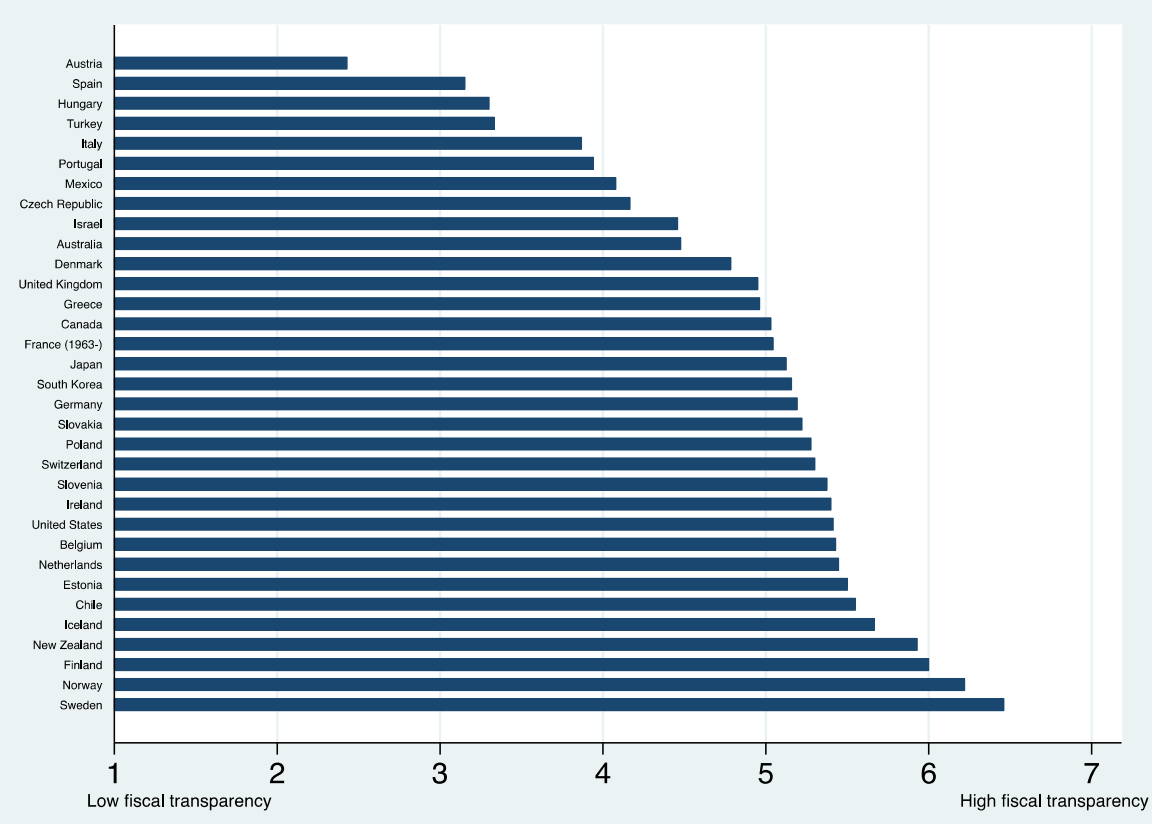

Fig. 7 Fiscal transparency in OECD countries 


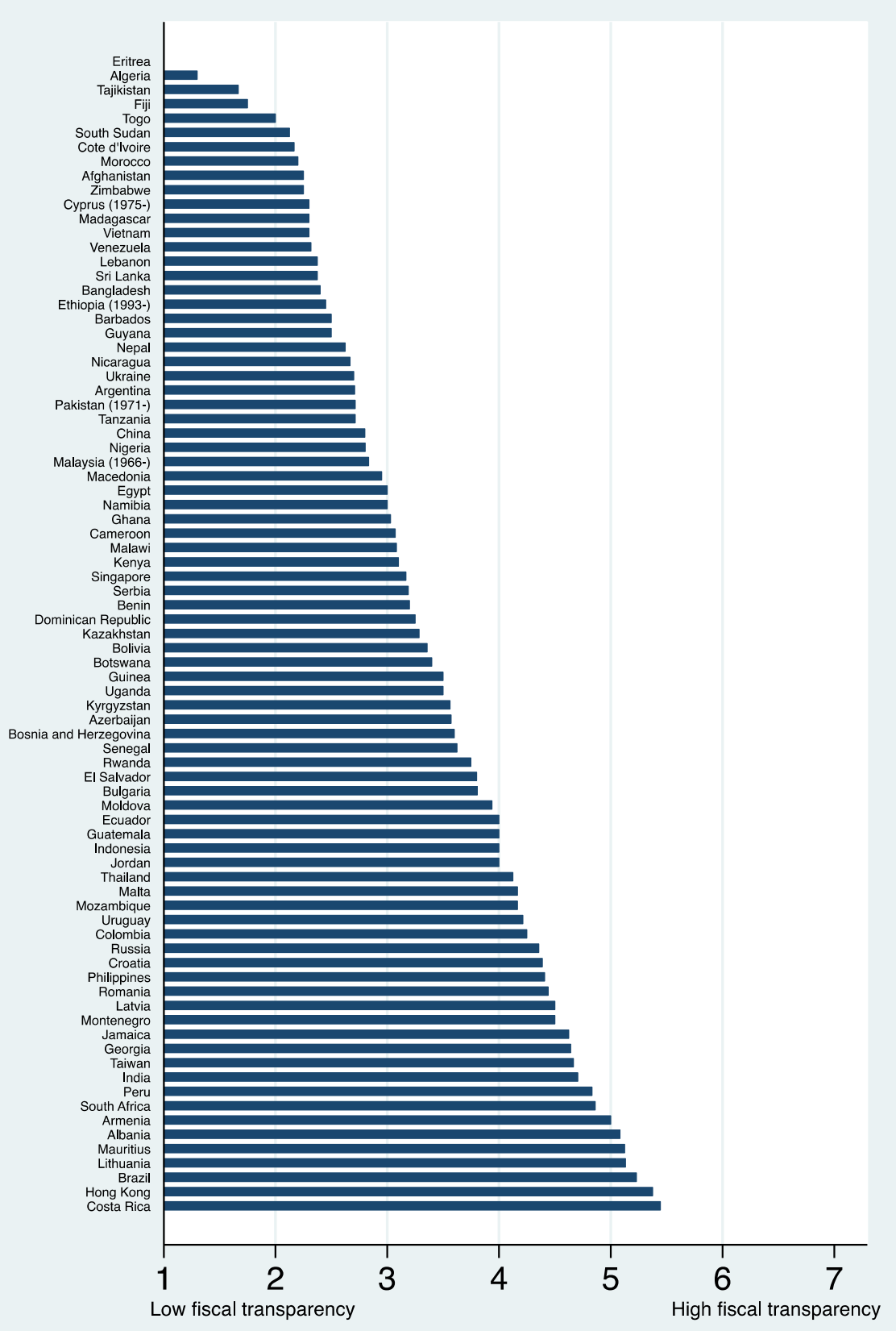

Fig. 8 Fiscal transparency in non OECD countries 
Open Access This article is distributed under the terms of the Creative Commons Attribution 4.0 International License (http://creativecommons.org/licenses/by/4.0/), which permits unrestricted use, distribution, and reproduction in any medium, provided you give appropriate credit to the original author(s) and the source, provide a link to the Creative Commons license, and indicate if changes were made.

\section{References}

1. Bauhr, M., \& Grimes, M. (2014). Indignation or resignation: The implications of transparency for societal accountability. Governance, 27(2), 291-320.

2. Bauhr, M., \& Nasiritousi, N. (2012). Resisting transparency: Corruption, legitimacy, and the quality of global environmental policies. Global Environmental Politics, 12(4), 9-29.

3. Islam, R. (2006). Does more transparency go along with better governance? Economics and Politics, 18(2), 121-167.

4. Kosack, S., \& Fung, A. (2014). Does transparency improve governance? Annual Review of Political Science, 17(1), 65-87. doi:10.1146/annurev-polisci-032210-144356.

5. Stiglitz, J. (2002). Transparency in government. The Right to Tell. World Bank, Washington, DC.

6. UNODC. (2004). United Nations convention against corruption, priorities for the provision of technical assistance. Global Programme against Corruption, July, http://www.unodc. org/pdf/crime/corruption/corruption_gpac_strategy_jul04.pdf.

7. Stasavage, D. (2004). Open-door or closed-door? Transparency in domestic and international bargaining. International Organization, 58(4), 667-703.

8. Florini, Ann. 2007. The right to know. Transparency for and Open World. New York: Colombia University Press.

9. Cucciniello, M., Porumbescu, G. A., \& Grimmelikhuijsen, S. (2016). 25 years of transparency research: Evidence and future directions. Public Administration Review, n/a-n/a. doi:10.1111/puar.12685.

10. Mitchell, R. B. (1998). Sources of transparency: Information Systems in International Regimes. International Studies Quarterly, 42(1), 109-130. doi:10.1111/0020-8833.00071.

11. Relly, J. E., \& Sabharwal, M. (2009). Perceptions of transparency of government policymaking: A crossnational study. Government Information Quarterly, 26(1), 148-157.

12. Chong, A., De La O, A. L., Karlan, D., \& Wantchekon, L. (2015). Does corruption information inspire the fight or quash the hope? A field experiment in Mexico on voter turnout, choice, and party identification. The Journal of Politics, 77(1), 55-71. doi:10.1086/678766.

13. Reinikka, R., \& Svensson, J. (2005). Fighting corruption to improve schooling: Evidence from a newspaper campaign in Uganda. Journal of the European Economic Association, 2(2-3), 259-267.

14. Winters, M. S., \& Weitz-Shapiro, R. (2013). Lacking information or condoning corruption: When do voters support corrupt politicians? Comparative Politics, 45(4), 418-436. doi:10.5129/001041513 X13815259182857.

15. Adserà, A., Boix, C., \& Payne, M. (2003). Are you being served? Political accountability and quality of government. The Journal of Law, Economics, \& Organization, 19(2), 445-490.

16. Hollyer, J. R., Rosendorff, B. P., \& Vreeland, J. R. (2014). Measuring transparency. Political Analysis, 22(4), 413-434. doi:10.1093/pan/mpu001.

17. Lindstedt, C., \& Naurin, D. (2010). Transparency is not enough: Making transparency effective in reducing corruption. International Political Science Review, 31(3), 301-322.

18. Fukuyama, F. (2015). Why is democracy performing so poorly? Journal of Democracy, 26(1): 11-20.

19. Collier, D., \& Mahon, J. E. (1993). Conceptual 'stretching' revisited: Adapting categories in Comparative analysis. The American Political Science Review, 87(4), 845-855. doi:10.2307/2938818.

20. Lindberg, S. I. (2013). Mapping accountability: Core concept and subtypes. International Review of Administrative Sciences, 79(2), 202-226. doi:10.1177/0020852313477761.

21. Sartori, G. (1970). Concept Misformation in Comparative Politics. The American Political Science Review, 64(4), 1033-1053. doi:10.2307/1958356.

22. Hood, C., \& Heald, D. (Eds.). (2006). Transparency: The key to better governance? Proceedings of the British Academy (135). Oxford: Oxford University Press ISBN 9780197263839.

23. Bellver, A. \& Kaufmann, D. (2005). Transparenting transparency: Initial empirics and policy applications. World Bank Policy Research Working Paper.

24. Michener, G., \& Bersch, K. (2013). Identifying transparency. Information Polity, 18(3), $233-242$. doi:10.3233/IP-130299. 
25. Michener, G. (2015). Policy evaluation via composite indexes: Qualitative lessons from international transparency policy indexes. World Development, 2015(74), 184-196.

26. Chambers, S. (2003). Deliberative democracy theory. Annual Review of Political Science, 6(1), 307-326.

27. Naurin, D. (2007). Deliberation behind closed doors: Transparency and lobbying in the European Union. Colchester: ECPR Press.

28. Malesky, E., Schuler, P., \& Tran, A. (2012). The adverse effects of sunshine: A field experiment on legislative transparency in an authoritarian assembly. American Political Science Review, 106(4), 762-786.

29. Fox, J. (2007). The uncertain relationship between transparency and accountability. Development in Practice, 17(4/5), 663-771.

30. Kaufmann, D. (2002). Transparency, incentives and prevention (TIP) for corruption control and good governance empirical findings, practical lessons, and strategies for action based on international experience. Background paper for Qinghua university-Carnegie conference on economic reform and good governance: Fighting corruption in transition economies, Beijing, April 11-12th, 2002.

31. Vishwanath, T., \& Kaufmann, D. (1999). Towards transparency in finance and governance. In Policy research Working paper. World Bank: Washington D.C.

32. Besley, T. (2006). Principled agents? The political economy of good government. Oxford: Oxford University Press.

33. Rose-Ackerman, S. (1999). Corruption and government: Causes, consequences, and reform. Cambridge: Cambridge University Press.

34. Besley, T., \& Persson, T. (2007). The origins of state capacity: Property rights, taxation, and Politics. NBER Working paper no. 13028 .

35. Geddes, B. (1994). Politician's dilemma: Building state capacity in Latin America. University of California Press.

36. Soifer, H. (2012). Measuring state capacity in contemporary Latin America. Revista de Ciencia Politica., 32(3), 585-598.

37. Brunetti, A., \& Weder, B. (2003). A free press is bad news for corruption. Journal of Public Economics, 87(7-8), 1801-1824. doi:10.1016/S0047-2727(01)00186-4.

38. Besley, T. J., \& Burgess, R. (2002). The political economy of government responsiveness: Theory and evidence from India. Quarterly Journal of Economics, 117(4), 1415-1452.

39. Scheppele, K. L. (2013). The rule of law and the Frankenstate: Why governance checklists do not work. Governance, 26(4), 559-562. doi:10.1111/gove.12049.

40. Grigorescu, A. (2003). International organizations and government transparency: Linking the international and domestic realm. International Studies Quarterly, 47(4), 643-667.

41. Seifert, J., Carlitz, R., \& Mondo, E. (2013). The Open Budget Index (OBI) as a comparative statistical tool. Journal of Comparative Policy Analysis: Research and Practice, 15(1), 87-101. doi:10.1080 /13876988.2012.748586.

42. Treisman, D. (2007). What have we learned about the causes of corruption from ten years of crossNational Empirical Research? Annual Review of Political Science, 10(1), 211-244. doi:10.1146/annurev. polisci.10.081205.095418.

43. Miceli, M. P., \& Near, J. P. (2002). Blowing the whistle. New York: Lexington Books.

44. Brown, A. J., Lewis, D., Moberly, R., \& Vandekerckhove, W. (2014). International handbook on whistleblowing research. Cheltenham and Northampton: Edward Elgar Publishing.

45. Dworkin, T. M. (2002). Whistleblowing, MNC's and peace. Vanderbilt Journal of transitional law. Working paper number 437.

46. Miethe, T. D., \& Rothschild, J. (1994). Whistleblowing and the control of organizational misconduct. Sociological Inquiry, 64(3), 322-347.

47. Callahan, E., Dworkin, T., \& Lewis D. (2004). Whistleblowing: Australian, UK and US approaches to disclosure in the public interest. Virginia Journal of International Law, 44(879) 148-164.

48. Banisar, D. (2011a). Whistleblowing: International standards and developments. Corruption and Transparency: Debating the Frontiers Between State, Market and Society, I. Sandoval, ed., World Bank-Institute for Social Research, UNAM, Washington, D.C., 2011a. https://ssrn. com/abstract=1753180.

49. Banisar, D. (2011b). Whistleblowing: International standards and developments. SSRN scholarly paper ID 1753180. Rochester: Social Science Research Network. https://papers.ssrn.com/abstract=1753180.

50. Thomas, M. (2010). What do the worldwide governance indicators measure? European Journal of Development Research, 22(1), 31-54.

51. Dahlström, C., Teorell, J., Dahlberg, S., Hartmann, F., Lindberg, A., \& Nistotskaya, M. (2015). The QoG expert survey dataset II. Gothenburg: University of Gothenburg, The Quality of Government Institute. 
52. Schwab, K., \& Sala-i-Martin, X. (2015). The global competitiveness report 2014-2015. World Economic Forum.

53. Teorell, J., Dahlberg, S., Holmberg, S., Rothstein, B., \& Svensson, R. (2015). The quality of government standard dataset, version Jan15. Gothenburg: University of Gothenburg: The Quality of Government Institute.

54. Boräng, F., Cornell, A., Grimes, M., \& Schuster, C. (2017). Cooking the books: Bureaucratic politicization and policy knowledge. Governance. doi:10.1111/gove.12283.

55. Boix, C., Miller, M., \& Rosato, S. (2012). A complete data set of political regimes, 1800-2007. Comparative Political Studies. doi:10.1177/0010414012463905.

56. Gleditsch, K. S. (2002). Expanded trade and GDP data. The Journal of Conflict Resolution; Beverly Hills, 46(5), 712-724.

57. Ades, A., \& Di Tella, R. (1997). The new Economics of corruption: A survey and some new results. Political Studies, 45(3), 496-515. doi:10.1111/1467-9248.00093.

58. La Porta, R., Lopez-De-Silanes, F., Shleifer, A., \& Vishny, R. W. (1999). "The quality of government." The Journal of Law. Economics and Organization, 15(1), 222-279.

59. Alesina, A., Devleeschauwer, A., Easterly, W., Kurlat, S., \& Wacziarg, R. (2003). Fractionalization. Journal of Economic Growth, 8, 155-194.

60. Alesina, A., \& Spolaore, E. (1997). On the number and size of nations. Quarterly Journal of Economics, $112(4), 1027-1056$.

61. Cerqueti, R., Coppier, R., \& Piga, G. (2011). Corruption, growth and ethnic fractionalization: A theoretical model. Journal of Economics, 106(2), 153-181. doi:10.1007/s00712-011-0253-5.

62. Shleifer, A., \& Vishny, R. W. (1993). Corruption. The Quarterly Journal of Economics, 108(3), 599-617. doi: $10.2307 / 2118402$.

63. Alesina, A., \& Drazen, A. (1991). Why are stabilizations delayed. American Economic Review, 81(5), $1170-1188$.

64. Dollar, D., Fisman, R., \& Gatti, R. (2001). Are women really the 'fairer' sex? Corruption and women in government. Journal of Economic Behavior \& Organization, 46(4), 423-429. doi:10.1016/S0167-2681 (01)00169-X.

65. Esarey, J., \& Chirillo, G. (2013). 'fairer sex' or purity myth? Corruption, Gender, and institutional context. Politics \& Gender, 9(4), 361-389. doi:10.1017/S1743923X13000378.

66. Swamy, A., Knack, S., Lee, Y., \& Azfar, O. (2001). Gender and corruption. Journal of Development Economics, 64(1), 25-55. doi:10.1016/S0304-3878(00)00123-1.

67. Gerring, J., \& Thacker, S. C. (2004). Political institutions and corruption: The role of unitarism and parliamentarism. British Journal of Political Science, 34, 295-330.

68. Kurtzman, J., Yago, G., \& Phumiwasana, T. (2004). The global costs of opacity - Measuring business and investment risk worldwide. MIT Sloan Management Review, 46(1), 38-44.

69. Montinola, G. R., \& Jackman, R. W. (2002). Sources of corruption: A crosscountry study. British Journal of Political Science, 32(01), 147-170.

70. Williams, A. (2015). A global index of information transparency and accountability. Journal of Comparative Economics, 43(3), 804-824. doi:10.1016/j.jce.2014.10.004.

71. Teorell, J., Coppedge, M., Skaaning, S. E., \& Lindberg, S. (2016). Measuring electoral democracy with VDem data: Introducing a new polyarchy index. V-Dem working paper 2016:25. https://www.v-dem. net/media/filer_public/fl/b7/f1b76fad-5d9b-41e3-b752-07baaba72a8c/v-dem_working_paper_2016_25. pdf. Accessed 7 July 2017

72. Bauhr, M. (2016). Need or greed? Conditions for collective action against corruption. Governance, August, n/a-n/a. doi:10.1111/gove.12232. 